\title{
Poly(arylene benzimidazole)s as novel high-performance polymers
}

\begin{abstract}
Guanjun Chang ${ }^{1}$, Junxiao Yang${ }^{1}$, Yawen Huang ${ }^{1}, \mathrm{Ke} \mathrm{Cao}^{1}$ and Lin Zhang ${ }^{2}$
Series of novel poly(arylene benzimidazole)s (PABIs) was obtained by condensation polymerization of aromatic bifluorides with the monomers of di(benzimidazolyl)benzenes (synthesized by reaction of the isomeric phthalic acids with $o$-phenylenediamine) via a $\mathbf{C}-\mathbf{N}$ coupling reaction. The structures of this series of polymers were characterized by Fourier transform infrared, proton nuclear magnetic resonance $\left({ }^{1} \mathrm{H}\right.$ NMR) spectroscopy and elemental analysis, and the results showed good agreement with the proposed structures. These synthesized polymers exhibited relatively high glass-transition temperatures $\left(T_{\mathrm{g}}>240^{\circ} \mathrm{C}\right)$, good thermal stability with high decomposition temperatures $\left(T_{\mathrm{d}}>450^{\circ} \mathrm{C}\right)$ and excellent solubility in organic solvents. On the atomic scale, the molecular simulation results indicated that the PABI polymers exhibited a zigzag molecular chain structure with a high free volume fraction due to the different linkage modes of the monomers in the polymerization process. On the macro level, the PABI polymers possessed high tensile strength with good toughness; the mechanical behavior of the PABI polymers indicates that they can be considered a new class of high-performance polymers.
\end{abstract}

Polymer Journal (2013) 45, 1188-1194; doi:10.1038/pj.2013.51; published online 5 June 2013

Keywords: C-N coupling reaction; high-performance polymer; poly(arylene benzimidazole)s

\section{INTRODUCTION}

Along with the ever-increasing demand in recent decades for highperformance materials in industries such as aerospace, machinery and electronics, significant progress has been achieved in the development of heat-resistant high-performance polymers, and these high-performance heterocyclic materials, such as polyimide, polybenzimidazole (PBI) and polypyrrolone, have been widely applied. ${ }^{1-6}$ In particular, as a type of heat-resistant high-performance polymer, PBI has been developed into a high-performance fiber, a special high-temperature adhesive, a monolithic material and a high-performance film, and it is the best choice for use in special environments and severe conditions because of its outstanding properties, such as thermal stability, chemical stability and resistance against acid and alkali. ${ }^{7-12}$ However, there are three issues that currently hinder the application of PBI. First, 3,3',4,4'-tetraaminobiphenyl, one of the monomers required for the preparation of $\mathrm{PBI}$, is expensive; thus, the preparation cost of PBI is also relatively high. Second, the solubility of PBI is poor, and it can only be prepared into a monolithic material by means of hot pressing. Third, the impact resistance of PBI is poor, and thus, it is impractical to use PBI to form shapes with sharp angles. To address the above-mentioned problems, much research has been dedicated to understanding the structural variation of PBI polymers to control and improve their properties. ${ }^{13-18}$ One such effort involves the substitution of the potentially reactive $\mathrm{N}-\mathrm{H}$ site in benzimidazole by functional groups, ${ }^{7,19-24}$ thereby enabling a $\mathrm{C}-\mathrm{N}$ coupling reaction with activated halides at the appropriate temperature. ${ }^{25-27}$ In addition, to improve the processability of $\mathrm{PBI}$, the ether, sulfone and other functional groups in PBI polymers can be modified to lower the thermo-oxidative stability but increase the solubility and flexibility of PBI, which allows further processing and modification (cross-linking and sulfonation to high ion-exchange capacity) of PBI and enables the production of films with good mechanical properties. ${ }^{28,29}$ However, chemical modification of PBI will also increase the costs associated with it.

As the $\mathrm{H}$ atoms on the $1-\mathrm{N}$ atoms in the PBI molecular chains feature certain activities, our aim herein is to use the $\mathrm{C}-\mathrm{N}$ coupling reaction to synthesize a series of poly(arylene benzimidazole)s (PABIs) as the basis of new structural polymers. The polymers synthesized are expected to have improved solubility in organic solvents while maintaining good thermal stability and high tensile strength with good toughness.

\section{EXPERIMENTAL PROCEDURE}

Primary materials and measurements

Isomeric phthalic acids and $o$-phenylenediamine (or its derivants) were purchased from Daikin Fine Chemical Laboratory, LTD, Tokyo, Japan. The

${ }^{1}$ State Key Laboratory Cultivation Base for Nonmetal Composite and Functional Materials, School of Material Science and Engineering, Southwest University of Science and Technology, Mianyang, People's Republic of China and 2Joint Laboratory for Extreme Conditions Matter Properties, Southwest University of Science and Technology, Research Center of Laser Fusion, China Academy of Engineering Physics, Mianyang, People's Republic of China

Correspondence: Dr G Chang, State Key Laboratory Cultivation Base for Nonmetal Composite and Functional Materials, School of Material Science and Engineering, Southwest University of Science and Technology, Mianyang 621010, China.

E-mail: gjchang@mail.ustc.edu.cn

Received 23 December 2012; revised 16 April 2013; accepted 16 April 2013; published online 5 June 2013 
traditional PBI with sulfone group (PSBI) was synthesized in our laboratory using 3,3'-diaminobenzidine with 4,4'-dicarboxydiphenyl sulfone, with $M_{\mathrm{n}}=25600$ and $M_{\mathrm{w}}=78500$. The remaining materials and reagents were obtained from different commercial sources and used without further purification.

Fourier transform infrared (FTIR) spectra were recorded using a Thermo Nicolet 6700 FTIR spectrometer (Boston, MA, USA). The elemental analysis characterization technique was performed using a Vario EL III apparatus (Elementar, Bonn, Germany). Proton nuclear magnetic resonance ( ${ }^{1} \mathrm{H}$ NMR) measurements were performed using a Bruker AVANCE $500 \mathrm{MHz}$ NMR spectrometer (Brook, Switzerland), with a solution of dimethyl sulfoxide (DMSO) $-d_{6}$. The molecular weights and molecular-weight distributions were estimated by gel permeation chromatography on a Wyatt DAWN HELEOS instrument (Santa Barbara, CA, USA), using dimethylformamide as an eluent at a testing temperature of $50{ }^{\circ} \mathrm{C}$. The glass-transition temperature was determined by analyzing differential scanning calorimetry curves, which were collected at a rate of $10^{\circ} \mathrm{C} \mathrm{min}^{-1}$ under flowing nitrogen gas. The thermogravimetric analysis characterization technique was performed on a Mettler TC $10 \mathrm{~A}$ instrument (Zurich, Switzerland), at a heating rate of $10^{\circ} \mathrm{C} \mathrm{min}{ }^{-1}$ under nitrogen atmosphere. The mechanical properties were determined using a universal testing machine at a tensile rate of $1 \mathrm{~mm} \mathrm{~min}^{-1}$.

\section{Molecular simulations}

The structures of the PABI polymers were determined using the Amorphous Cell Module of the Materials Studio program (MS, version 4.4, Accelrys Software Inc., San Diego, CA, USA). The polymer-consistent force field approach was selected. The time step in all of the simulations was $1 \mathrm{fs}$. The smart minimizer method with 5000 iterations was used to achieve the initial lowest energy structures of the PABI. Next, the dynamic module Discover was run to achieve molecular equilibration, with a running dynamic of $50 \mathrm{ps}$ in the NVT (constant volume and temperature) ensemble. Using the Amorphous Cell Module, molecular dynamic simulations for PABI, 1000 ps in duration, were then performed under periodic boundary conditions. The simulation process was performed at room temperature $(298 \mathrm{~K})$, setting the degree of polymerization to $N=15$ of poly(arylene benzimidazole)s (PABI) for the simulation process. The density of PABI is $P=1.2 \mathrm{~g} \mathrm{~cm}^{-3}$. The optimized structure of the polymer was obtained through the simulation processes described above.

\section{Synthesis of di(benzimidazolyl)benzenes}

A 50-ml, three-neck, round-bottomed flask equipped with a magnetic stirrer, a water-cooled condenser and an argon inlet and outlet was charged with a mixture of 1,2-phenylenediamine (or its derivants) $(0.0084 \mathrm{~mol})$, isomeric phthalic acid $(0.004 \mathrm{~mol})$ and $16 \mathrm{ml}$ polyphosphoric acid. The temperature was slowly raised to $200{ }^{\circ} \mathrm{C}$, and the reaction mixture was heated for $6 \mathrm{~h}$. The resulting solution was allowed to slowly cool to room temperature and was subsequently poured into cold water. Next, the solution was dropped into a $15 \% \mathrm{NaOH}$ solution and neutralized to $\mathrm{pH}=8$. After the solution was filtered through Celite, it was washed with water and dried. The obtained crude product was twice recrystallized and dried in vacuum at $60^{\circ} \mathrm{C}$. The typical synthetic procedure of di(benzimidazolyl)benzenes is shown in Scheme 1. The structures of the di(benzimidazolyl)benzenes were characterized by means of FTIR and ${ }^{1} \mathrm{H}$ NMR spectroscopy and by elemental analysis, and the characterization results indicated agreement with the proposed structure. As an example, the ${ }^{1} \mathrm{H}$ NMR spectroscopy results of di(benzimidazolyl)benzene sulfone (BIS) are shown in Figure $1\left(\right.$ DMSO- $\left.d_{6}\right)$.

\section{General procedure for the synthesis of PABI}

A 50-ml, three-necked, round-bottom flask equipped with a magnetic stirrer, a water-cooled condenser and an argon inlet and outlet was filled with a mixture of di(benzimidazolyl)benzenes $(0.004 \mathrm{~mol})$, aromatic bifluorides $(0.004 \mathrm{~mol})$ and anhydrous potassium carbonate $(0.008 \mathrm{~mol})$ in $10 \mathrm{ml}$ of sulfolane and $5 \mathrm{ml}$ of chlorobenzene. The reaction mixture was heated to azeotrope off the resulting water with the chlorobenzene. The chlorobenzene was then removed, and the reaction mixture was heated to $230-240{ }^{\circ} \mathrm{C}$ for $6-12 \mathrm{~h}$. Next, the reaction mixture was cooled, and the solution was poured into water to

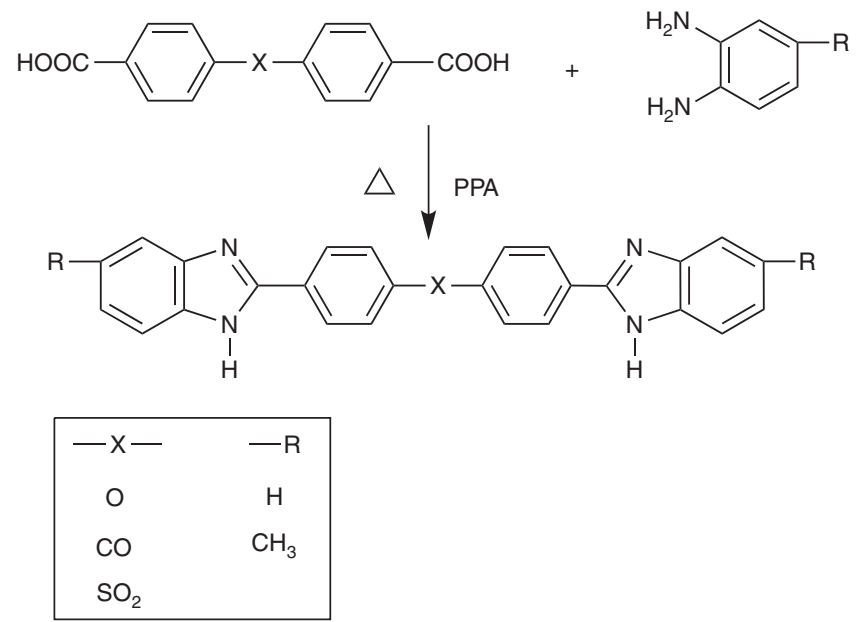

Scheme 1 Synthesis of di(benzimidazolyl)benzenes.

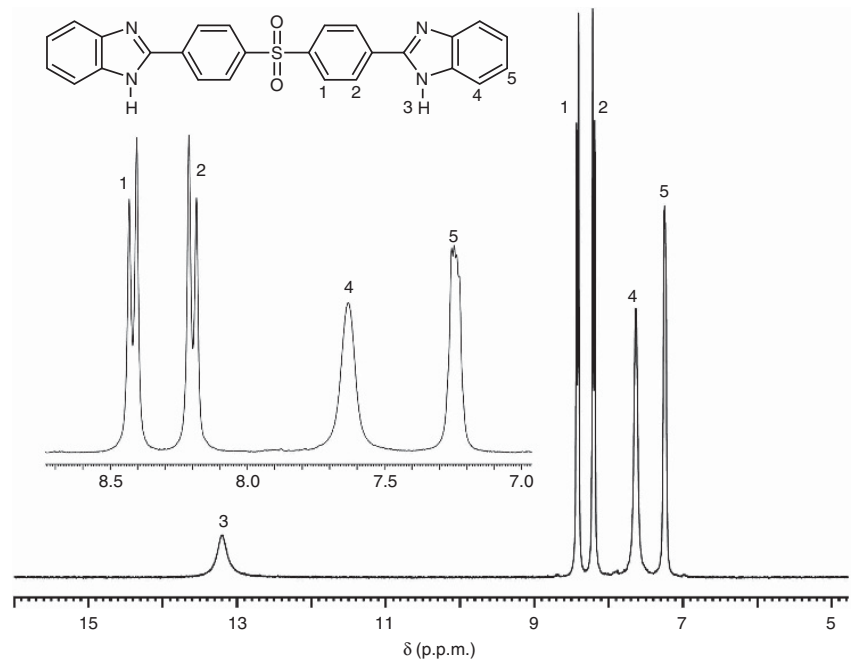

Figure 1 The ${ }^{1} \mathrm{H}$ NMR of di(benzimidazolyl)benzene sulfone.

precipitate out the polymer. Finally, the polymer was collected by filtration and dried in vacuum at $100{ }^{\circ} \mathrm{C}$ for $8 \mathrm{~h}$.

P1: Yield: $\quad 95 \% ; \quad{ }^{1} \mathrm{H} \quad \mathrm{NMR} \quad \delta: \quad 8.31(\mathrm{~d}, 4 \mathrm{H}, \mathrm{ArH}), \quad 8.15(\mathrm{~d}, 4 \mathrm{H}, \mathrm{ArH})$, 8.01(d,4H,ArH), 7.55(d,4H,ArH), 7.64(d,4H,ArH) and 7.26(t,4H,ArH); IR spectra (KBr pellet): $3043 \mathrm{~cm}^{-1}(\mathrm{Ar}-\mathrm{H}), 1623 \mathrm{~cm}^{-1}(\mathrm{C}=\mathrm{N})$ and $1170 \mathrm{~cm}^{-1}$ (C-O-C); MS (EI): 616.08; Analytical calculated (Anal. calcd) for $\mathrm{C}_{38} \mathrm{H}_{24} \mathrm{~N}_{4} \mathrm{O}_{3} \mathrm{~S}(616.08)$ : C 74.03, H 3.90, O 7.79 and N 9.09; found: $\mathrm{C} 74.18$, $\mathrm{H}$ 3.59, O 7.66 and $\mathrm{N} 9.15$.

P2: Yield: $\quad 92 \% ; \quad{ }^{1} \mathrm{H} \quad$ NMR $\quad \delta: \quad 8.41(\mathrm{~d}, 8 \mathrm{H}, \mathrm{ArH}), \quad 8.20(\mathrm{~d}, 8 \mathrm{H}, \mathrm{ArH})$, $7.65(\mathrm{~d}, 4 \mathrm{H}, \mathrm{ArH})$ and $7.25(\mathrm{t}, 4 \mathrm{H}, \mathrm{ArH})$; IR spectra ( $\mathrm{KBr}$ pellet): $3047 \mathrm{~cm}^{-1}$ $(\mathrm{Ar}-\mathrm{H}), 1625 \mathrm{~cm}^{-1}(\mathrm{C}=\mathrm{N})$ and $1156 \mathrm{~cm}^{-1}(\mathrm{C}-\mathrm{S}-\mathrm{C})$; $\mathrm{MS}$ (EI): 664.10; Anal. calcd for $\mathrm{C}_{38} \mathrm{H}_{24} \mathrm{~N}_{4} \mathrm{O}_{4} \mathrm{~S}_{2}(664.10)$ : C 68.67, H 3.62, O 9.64 and N 8.43; found: C 68.33, H 3.88, O 9.91 and $\mathrm{N} 8.03$.

P3: Yield: $\quad 91 \% ; \quad{ }^{1} \mathrm{H} \quad$ NMR $\quad \delta: \quad 8.38(\mathrm{~d}, 4 \mathrm{H}, \mathrm{ArH}), \quad 8.32(\mathrm{~d}, 4 \mathrm{H}, \mathrm{ArH})$, 8.15(d,4H,ArH $), 8.10(\mathrm{~d}, 4 \mathrm{H}, \mathrm{ArH}), \quad 7.63(\mathrm{~d}, 4 \mathrm{H}, \mathrm{ArH})$ and $7.24(\mathrm{t}, 4 \mathrm{H}, \mathrm{ArH})$; IR spectra (KBr pellet): $3047 \mathrm{~cm}^{-1}(\mathrm{Ar}-\mathrm{H}), 1677 \mathrm{~cm}^{-1}(\mathrm{C}=\mathrm{O})$ and $1621 \mathrm{~cm}^{-1}$ $(\mathrm{C}=\mathrm{N})$; MS (EI): 628.03; Anal. calcd for $\mathrm{C}_{39} \mathrm{H}_{24} \mathrm{~N}_{4} \mathrm{O}_{3} \mathrm{~S}$ (628.03): C 74.52, $\mathrm{H}$ 3.82, O 7.64 and $\mathrm{N}$ 8.92; found: C 74.21, H 4.02, O 7.83 and $\mathrm{N} 9.01$.

P4: Yield: $\quad 90 \% ; \quad{ }^{1} \mathrm{H} \quad$ NMR $\quad \delta: \quad 8.30(\mathrm{~d}, 4 \mathrm{H}, \mathrm{ArH}), \quad 8.16(\mathrm{~d}, 4 \mathrm{H}, \mathrm{ArH})$, 8.00(d,4H,ArH $), \quad 7.63(\mathrm{~d}, 4 \mathrm{H}, \mathrm{ArH}), \quad 7.57(\mathrm{~d}, 2 \mathrm{H}, \mathrm{ArH}), \quad 7.51(\mathrm{~s}, 2 \mathrm{H}, \mathrm{ArH})$, 7.05( $\mathrm{d}, 2 \mathrm{H}, \mathrm{ArH})$ and $2.34\left(\mathrm{t}, 6 \mathrm{H}, \mathrm{CH}_{3}\right)$; IR spectra $\left(\mathrm{KBr}\right.$ pellet): $3033 \mathrm{~cm}^{-1}$ $(\mathrm{Ar}-\mathrm{H}), 2923 \mathrm{~cm}^{-1}\left(-\mathrm{CH}_{3}\right), 1622 \mathrm{~cm}^{-1}(\mathrm{C}=\mathrm{N})$ and $1164 \mathrm{~cm}^{-1}(\mathrm{C}-\mathrm{O}-\mathrm{C})$; 
MS (EI): 644.15; Anal. calcd for $\mathrm{C}_{40} \mathrm{H}_{28} \mathrm{~N}_{4} \mathrm{O}_{3} \mathrm{~S}$ (644.15): C 74.53, H 4.35, O 7.45 and N 8.70; found: C 74.14, H 4.55, O 7.75 and N 8.36.

P5: Yield: $\quad 97 \%$; $1 \mathrm{H} \quad$ NMR $\quad \delta: \quad 8.41(\mathrm{~d}, 8 \mathrm{H}, \mathrm{ArH}), \quad 8.21(\mathrm{~d}, 8 \mathrm{H}, \mathrm{ArH})$, 7.57(d,2H,ArH $), 7.49(\mathrm{~s}, 2 \mathrm{H}, \mathrm{ArH}), \quad 7.05(\mathrm{~d}, 2 \mathrm{H}, \mathrm{ArH})$ and $2.37(\mathrm{t}, 6 \mathrm{H}, \mathrm{CH} 3)$; IR spectra (KBr pellet):3036 cm $\mathrm{cm}^{-1}(\mathrm{Ar}-\mathrm{H}), 2927 \mathrm{~cm}^{-1}(-\mathrm{CH} 3), 1629 \mathrm{~cm}^{-1}$ $(\mathrm{C}=\mathrm{N})$ and $1153 \mathrm{~cm}^{-1}$ (C-S-C); MS (EI):692.11; Anal. calcd for $\mathrm{C}_{40} \mathrm{H}_{28} \mathrm{~N}_{4} \mathrm{O}_{4} \mathrm{~S}_{2}$ (692.11): C 69.36, H 4.05, O 9.25 and $\mathrm{N}$ 8.09; found: C 69.03, H 4.35, O 9.45 and $\mathrm{N} 8.03$.

P6: Yield: $\quad 96 \% ; \quad{ }^{1} \mathrm{H} \quad \mathrm{NMR} \quad \delta: \quad 8.37(\mathrm{~d}, 4 \mathrm{H}, \mathrm{ArH}), \quad 8.34(\mathrm{~d}, 4 \mathrm{H}, \mathrm{ArH})$, $8.17(\mathrm{~d}, 4 \mathrm{H}, \mathrm{ArH}), \quad 8.11(\mathrm{~d}, 4 \mathrm{H}, \mathrm{ArH}), \quad 7.55(\mathrm{~d}, 2 \mathrm{H}, \mathrm{ArH}), \quad 7.46(\mathrm{~s}, 2 \mathrm{H}, \mathrm{ArH})$, $7.03(\mathrm{~d}, 2 \mathrm{H}, \mathrm{ArH})$ and $2.35\left(\mathrm{t}, 6 \mathrm{H}, \mathrm{CH}_{3}\right)$; IR spectra $\left(\mathrm{KBr}\right.$ pellet): $3037 \mathrm{~cm}^{-1}$ $(\mathrm{Ar}-\mathrm{H}), 2931 \mathrm{~cm}^{-1}(-\mathrm{CH} 3), 1686 \mathrm{~cm}^{-1}(\mathrm{C}=\mathrm{O})$ and $1630 \mathrm{~cm}^{-1}(\mathrm{C}=\mathrm{N})$; MS (EI): 656.05; Anal. calcd for $\mathrm{C}_{41} \mathrm{H}_{28} \mathrm{~N}_{4} \mathrm{O}_{3} \mathrm{~S}$ (656.05):C 75.00, $\mathrm{H}$ 4.27, O 7.31 and $\mathrm{N}$ 8.54; found: C 74.90, $\mathrm{H} \mathrm{4.57,} \mathrm{O} 7.41$ and $\mathrm{N} 8.24$.

P7: Yield: $\quad 89 \% ; \quad{ }^{1} \mathrm{H} \quad \mathrm{NMR} \quad \delta: \quad 8.21(\mathrm{~d}, 4 \mathrm{H}, \mathrm{ArH}), \quad 8.14(\mathrm{~d}, 4 \mathrm{H}, \mathrm{ArH})$, 8.01(d,4H,ArH $), 7.54(\mathrm{~d}, 4 \mathrm{H}, \mathrm{ArH}), \quad 7.64(\mathrm{~d}, 4 \mathrm{H}, \mathrm{ArH})$ and $7.27(\mathrm{t}, 4 \mathrm{H}, \mathrm{ArH})$; IR spectra (KBr pellet): $3063 \mathrm{~cm}^{-1}(\mathrm{Ar}-\mathrm{H}), 1702 \mathrm{~cm}^{-1}(\mathrm{C}=\mathrm{O}), 1627 \mathrm{~cm}^{-1}$ $(\mathrm{C}=\mathrm{N})$ and $1169 \mathrm{~cm}^{-1} \quad(\mathrm{C}-\mathrm{O}-\mathrm{C})$; $\mathrm{MS}(\mathrm{EI})$ : 580.09; Anal. calcd for $\mathrm{C}_{39} \mathrm{H}_{24} \mathrm{~N}_{4} \mathrm{O}_{2}$ (580.09): C 80.69, H 4.14, O 5.52 and N 9.65; found: C 80.53, $\mathrm{H} 4.33$, O 5.58 and $\mathrm{N} 9.35$.

P8: Yield: $\quad 95 \% ; \quad{ }^{1} \mathrm{H} \quad$ NMR $\quad \delta: \quad 8.40(\mathrm{~d}, 4 \mathrm{H}, \mathrm{ArH}), \quad 8.27(\mathrm{~d}, 4 \mathrm{H}, \mathrm{ArH})$, 8.21(d,4H,ArH $), 8.16(\mathrm{~d}, 4 \mathrm{H}, \mathrm{ArH}), \quad 7.70(\mathrm{~d}, 4 \mathrm{H}, \mathrm{ArH})$ and $7.27(\mathrm{t}, 4 \mathrm{H}, \mathrm{ArH})$; IR spectra ( $\mathrm{KBr}$ pellet): $3057 \mathrm{~cm}^{-1}(\mathrm{Ar}-\mathrm{H}), 1674 \mathrm{~cm}^{-1}(\mathrm{C}=\mathrm{O}), 1624 \mathrm{~cm}^{-1}$ $(\mathrm{C}=\mathrm{N})$ and $1158 \mathrm{~cm}^{-1} \quad(\mathrm{C}-\mathrm{S}-\mathrm{C})$; $\mathrm{MS}$ (EI): 628.12; Anal. calcd for $\mathrm{C}_{39} \mathrm{H}_{24} \mathrm{~N}_{4} \mathrm{O}_{3} \mathrm{~S}$ (628.12): C 74.52, H 3.82, O 7.64 and $\mathrm{N} 8.92$; found: $\mathrm{C}$ 74.62, H 3.88, O 7.71 and $\mathrm{N} 8.52$.

P9: Yield: $\quad 86 \% ; \quad{ }^{1} \mathrm{H} \quad \mathrm{NMR} \quad \delta: \quad 8.35(\mathrm{~d}, 8 \mathrm{H}, \mathrm{ArH}), \quad 8.14(\mathrm{~d}, 8 \mathrm{H}, \mathrm{ArH})$, 7.63(d,4H,ArH) and 7.26(t,4H,ArH); IR spectra ( $\mathrm{KBr}$ pellet): $3056 \mathrm{~cm}^{-1}$ $(\mathrm{Ar}-\mathrm{H}), 1669 \mathrm{~cm}^{-1}(\mathrm{C}=\mathrm{O})$ and $1631 \mathrm{~cm}^{-1}(\mathrm{C}=\mathrm{N})$; MS (EI): 592.16; Anal. calcd for $\mathrm{C}_{40} \mathrm{H}_{24} \mathrm{~N}_{4} \mathrm{O}_{2}$ (592.16): C 81.08, H 4.05, O 5.41 and N 9.46; found: $\mathrm{C}$ 80.93, H 4.22, O 5.51 and $\mathrm{N} 9.51$.

P10: Yield: $\quad 95 \% ; \quad{ }^{1} \mathrm{H} \quad \mathrm{NMR} \quad \delta: \quad 8.31(\mathrm{~d}, 4 \mathrm{H}, \mathrm{ArH}), \quad 8.15(\mathrm{~d}, 4 \mathrm{H}, \mathrm{ArH})$, 8.00(d,4H,ArH $), \quad 7.54(\mathrm{~d}, 4 \mathrm{H}, \mathrm{ArH}), \quad 7.59(\mathrm{~d}, 2 \mathrm{H}, \mathrm{ArH}), \quad 7.45(\mathrm{~s}, 2 \mathrm{H}, \mathrm{ArH})$, $7.03(\mathrm{~d}, 2 \mathrm{H}, \mathrm{ArH})$ and $2.35\left(\mathrm{t}, 6 \mathrm{H}, \mathrm{CH}_{3}\right)$; IR spectra $(\mathrm{KBr}$ pellet $): 3048 \mathrm{~cm}^{-1}$ $(\mathrm{Ar}-\mathrm{H}), 2925 \mathrm{~cm}^{-1}\left(-\mathrm{CH}_{3}\right), 1701 \mathrm{~cm}^{-1}(\mathrm{C}=\mathrm{O}), 1628 \mathrm{~cm}^{-1}(\mathrm{C}=\mathrm{N})$ and $1169 \mathrm{~cm}^{-1}$ (C-O-C); MS (EI): 608.21; Anal. calcd for $\mathrm{C}_{41} \mathrm{H}_{28} \mathrm{~N}_{4} \mathrm{O}_{2}$ (608.21): C 80.92, H 4.61, O 5.26 and N 9.21; found: C 80.72, H 4.43, O 5.13 and N 9.56.

P11: Yield: $\quad 92 \% ; \quad{ }^{1} \mathrm{H} \quad \mathrm{NMR} \quad \delta: \quad 8.42(\mathrm{~d}, 4 \mathrm{H}, \mathrm{ArH}), \quad 8.35(\mathrm{~d}, 4 \mathrm{H}, \mathrm{ArH})$, $8.21(\mathrm{~d}, 4 \mathrm{H}, \mathrm{ArH}), \quad 8.10(\mathrm{~d}, 4 \mathrm{H}, \mathrm{ArH}), \quad 7.57(\mathrm{~d}, 2 \mathrm{H}, \mathrm{ArH}), \quad 7.50(\mathrm{~s}, 2 \mathrm{H}, \mathrm{ArH})$, 7.05(d,2H,ArH) and 2.34(t,6H,CH$)$; IR spectra ( $\mathrm{KBr}$ pellet): $3057 \mathrm{~cm}^{-1}(\mathrm{Ar}-$ $\mathrm{H}), \quad 2921 \mathrm{~cm}^{-1}\left(-\mathrm{CH}_{3}\right), \quad 1671 \mathrm{~cm}^{-1}(\mathrm{C}=\mathrm{O}), \quad 1622 \mathrm{~cm}^{-1}(\mathrm{C}=\mathrm{N})$ and $1160 \mathrm{~cm}^{-1}$ (C-S-C); MS (EI): 656.07; Anal. calcd for $\mathrm{C}_{41} \mathrm{H}_{28} \mathrm{~N}_{4} \mathrm{O}_{3} \mathrm{~S}$ (656.07): C 75.00, H 4.27, O 7.31 and N 8.54; found: C 75.07, H 4.39, O 7.54 and N 8.18.

P12: Yield: $89 \% ; \quad{ }^{1} \mathrm{H} \quad$ NMR $\quad \delta: \quad 8.40(\mathrm{~d}, 8 \mathrm{H}, \mathrm{ArH}), \quad 8.19(\mathrm{~d}, 8 \mathrm{H}, \mathrm{ArH})$, 7.58(d,4H,ArH $), 7.50(\mathrm{~d}, 2 \mathrm{H}, \mathrm{ArH}), 7.06(\mathrm{~d}, 2 \mathrm{H}, \mathrm{ArH})$ and $2.36\left(\mathrm{t}, 6 \mathrm{H}, \mathrm{CH}_{3}\right)$; IR spectra $\left(\mathrm{KBr}\right.$ pellet):3066 cm $\mathrm{cm}^{-1}(\mathrm{Ar}-\mathrm{H}), 2923 \mathrm{~cm}^{-1}\left(-\mathrm{CH}_{3}\right), 1664 \mathrm{~cm}^{-1}$ $(\mathrm{C}=\mathrm{O})$ and $1624 \mathrm{~cm}^{-1}(\mathrm{C}=\mathrm{N})$; $\mathrm{MS}$ (EI): 620.09; Anal. calcd for $\mathrm{C}_{42} \mathrm{H}_{28} \mathrm{~N}_{4} \mathrm{O}_{2}$ (620.09): C 81.29, H 4.52, O 5.16 and N 9.03; found:C 81.17, $\mathrm{H} 4.77$, O 5.32 and $\mathrm{N} 8.81$.

\section{RESULTS AND DISCUSSIONS}

\section{Synthesis of PABI}

In the preparation of poly(phthalazinone ether ketone), both $\mathrm{NH}$ and $\mathrm{OH}$ groups are present in the monomers, with the $\mathrm{NH}$ group behaving as a phenolic $\mathrm{OH}$ group in the aromatic nucleophilic displacement reaction (Scheme 2). ${ }^{30}$ In this paper, we were surprised

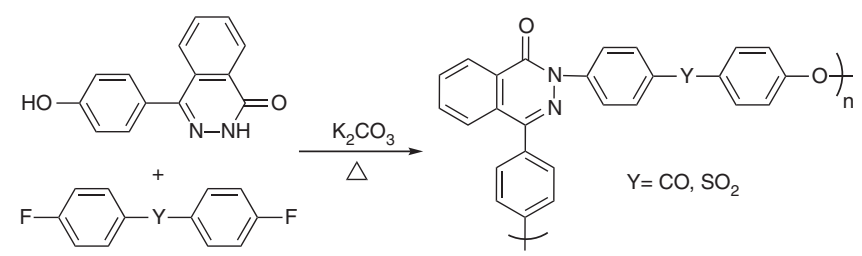

Scheme 2 Synthesis of polymers containing the phthalazinone groups. to find that the $\mathrm{NH}$ group in di(benzimidazolyl)benzenes also undergoes a $\mathrm{C}-\mathrm{N}$ coupling reaction with activated halides in the presence of anhydrous potassium carbonate. Herein, a series of novel PABIs have been obtained by condensation polymerization of aromatic bifluorides with di(benzimidazolyl)benzenes via a $\mathrm{C}-\mathrm{N}$ coupling reaction (Scheme 3).

Structurally, the synthesized PABI is obviously different from the traditional PBI. The micro conformation of the P2 and the traditional PSBI obtained from molecular simulation, as shown in Figure 2, indicate that PSBI is rigid and rod-like and that P2 has a zigzag molecular chain structure due to the different linkage modes of the monomer in the polymerization process. Compared with traditional PSBI, the different structure of PABI leads to different physical and chemical properties. All of the polymers synthesized were characterized by FTIR and ${ }^{1} \mathrm{H}$ NMR spectroscopy and by the elemental analysis technique, with the characterization results exhibiting good agreement with the proposed structure. As an example, the ${ }^{1} \mathrm{H}$ NMR spectrum of P9 is shown in Figure 3 (DMSO- $d_{6}$ ).

The molecular weights of the reprecipitated polymers were measured by gel permeation chromatography (calibrated by polystyrene standards). The $M_{\mathrm{n}}$ values were in the range of 8100-25300, and the $M_{\mathrm{w}}$ values were in the range of 22500-98000. The polydispersity index varied from 2.77 to 5.33 (Table 1 ).

\section{Thermal properties of PABI}

Compared with the molecular chain structure of PBI, the different molecular chain structures of PABI clearly influenced the packing of the molecular chain, the intermolecular distance and the intermolecular force, thereby resulting in different thermal properties. To explain such differences on the microscale, two typical polymers, shown in Figure 2, were selected in this study, and their respective cohesive energy densities (CEDs) were calculated by molecular simulation using the Amorphous Cell Module in Material Studio Software. The simulation produced CED values of $0.5872 \times 10^{8}$ and $1.0560 \times$ $10^{8} \mathrm{cal} / 10^{3}$ for P2 and PSBI, respectively. Although PABI featured comparatively weak intermolecular forces, these polymers still possessed high glass-transition temperatures (Table 2). Typical differential scanning calorimetry traces obtained under nitrogen atmosphere are shown in Figure 4 for polymers P2, P3, P5 and P7; the absence of a melting temperature suggests amorphous polymer structures. The $T_{\mathrm{g}} \mathrm{s}$ of PABI were lower than that of PBI (up to $\geqslant 300^{\circ} \mathrm{C}$ ), which correlated with the elimination of hydrogen bonding after the $\mathrm{N}$-substitution. The methyl group clearly hindered chain packing and reduced the level of ordering, thus contributing to the flexibility of the polymer; compared with P2, P5 exhibited a lower $T_{\mathrm{g}}$. The presence of a kinked ether group, which is known to induce loose chain packing in the backbone of polymers, led to a significant increase in the flexibility of the polymers, thus resulting in a lower $T_{\mathrm{g}}$ for P7.

Regarding their rigid skeletal structures, all of the PABI polymers exhibited high thermal stability with high decomposition temperatures (Table 2). Typical thermogravimetry (TG) traces obtained in nitrogen are shown in Figure 5 for the polymers P2, P3, P5 and P7. As evaluated by the $5 \%$ weight-loss point of the TG curves, the polymers were found to be thermally stable up to $460-550{ }^{\circ} \mathrm{C}$. The $50 \%$ weight losses of the polymers occurred at over $800{ }^{\circ} \mathrm{C}$ for PABI in nitrogen. Compared with PABI with methyl groups, the thermal stability of PABI with no methyl groups was superior. Char yield is a simple and important measurement that correlates with the ability to sustain combustion. The maximum char yield at $800{ }^{\circ} \mathrm{C}$ in nitrogen was obtained for polymer P4 (68\%), and the minimum was obtained for polymer P5 (54\%). 


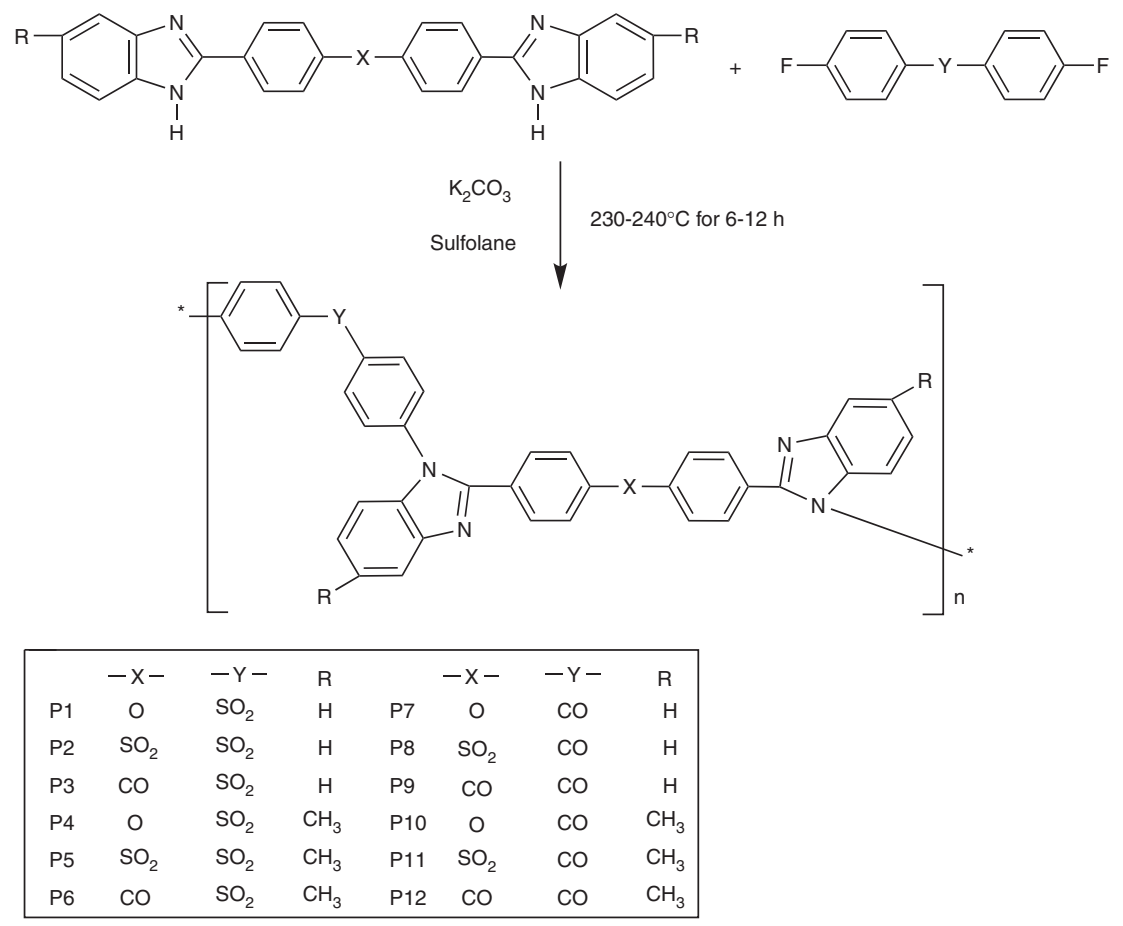

Scheme 3 Synthesis of PABIs.

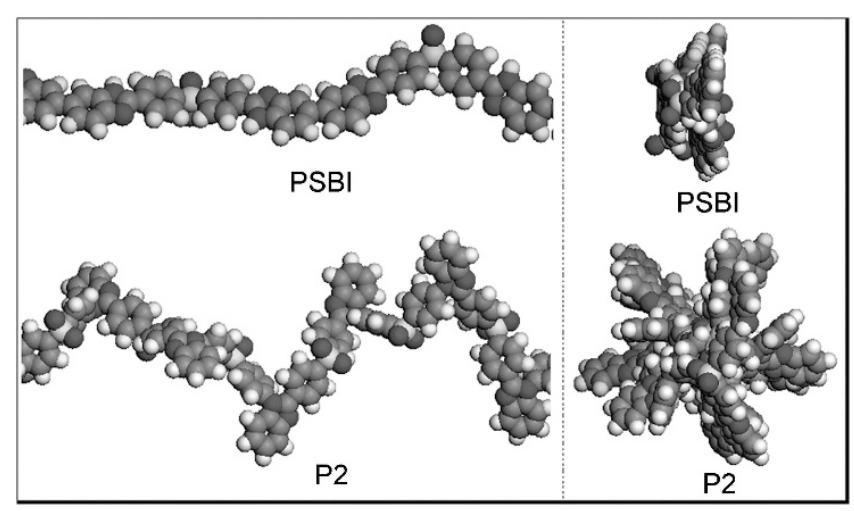

Figure 2 Three-dimensional stereostructures of P2 and PSBI. A full color version of this figure is available at Polymer Journal online.

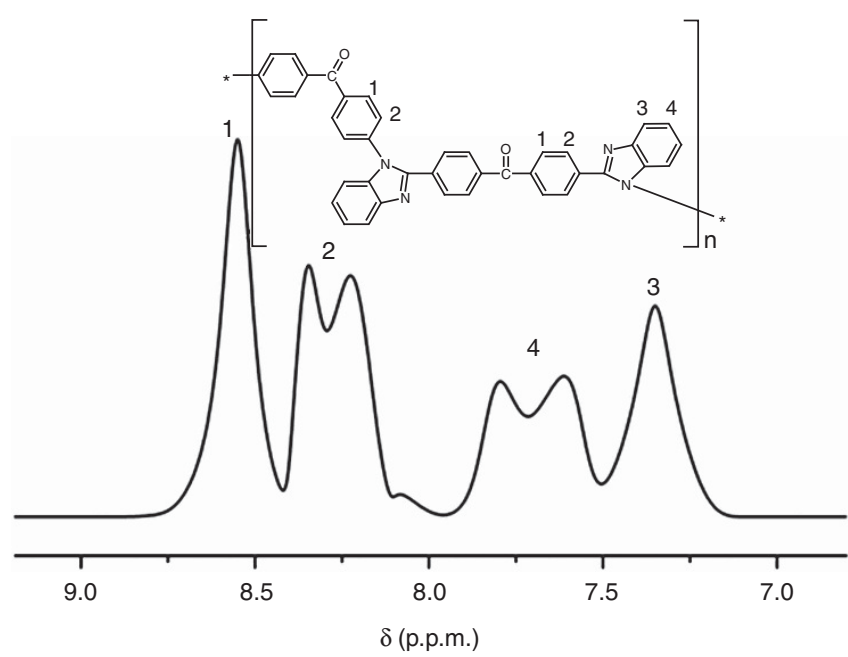

Figure $3{ }^{1} \mathrm{H}$ NMR spectra of P9 and PSBI in DMSO-d6.
Table 1 Molecular-weight polydispersity index of $\mathrm{PABI}$

\begin{tabular}{lrccc}
\hline Polymer code & $\mathrm{M}_{n}$ & $\mathrm{M}_{w}$ & $\mathrm{M}_{w} \mathrm{M}_{n}$ & Yield (\%) \\
\hline P1 & 19500 & 78900 & 4.04 & 89 \\
P2 & 23500 & 96700 & 4.11 & 96 \\
P3 & 12300 & 65600 & 5.33 & 91 \\
P4 & 22800 & 89600 & 3.92 & 95 \\
P5 & 20700 & 98000 & 4.73 & 92 \\
P6 & 15200 & 46900 & 3.08 & 89 \\
P7 & 15600 & 64500 & 4.13 & 90 \\
P8 & 25300 & 82000 & 3.24 & 88 \\
P9 & 8100 & 22500 & 2.77 & 84 \\
P10 & 11300 & 36900 & 3.26 & 89 \\
P11 & 13500 & 42300 & 3.13 & 87 \\
P12 & 8700 & 23000 & 2.64 & 81 \\
\hline
\end{tabular}

Abbreviation: PABI, poly(arylene benzimidazole).

aThe soluble fraction in dimethylformamide calibrated by gel permeation chromatography polystyrene standards.

\section{Solubility of PABI}

At one time, PBI was considered to be the most promising polymer for special applications in the automotive, aircraft and spacecraft industries because of its outstanding physical properties. However, the relatively poor solubility of PBI limits its further application. We expected the prepared PABI to exhibit good solubility and to have the ability to dissolve in polar organic solvents. Simulations of the soluble properties for P2 and PSBI were performed to verify our expectations. After dynamic equilibration, the CED was determined using the last $500 \mathrm{ps}$ of the trajectory files. The Flory-Huggins interaction parameter, $\chi$, is given by Equation (1):

$$
\chi=\frac{Z \cdot \Delta \mathrm{E}_{\operatorname{mix}}}{R T}
$$

where $Z$ is the coordination number (taken to be six for the cubic lattice model), $R$ is the molar gas constant $\left(\mathrm{cal} \mathrm{mol}^{-1}\right)$ and $T$ is the 
Table 2 Thermal behavior of PABI

\begin{tabular}{lccccc}
\hline Polymer code & $\mathrm{T}_{5}{ }^{\mathrm{a}}$ & $\mathrm{T}_{10} 0^{\mathrm{b}}$ & $\mathrm{T}_{30}{ }^{\mathrm{c}}$ & Char yield at $800^{\circ} \mathrm{C}^{\mathrm{d}}$ & $\mathrm{T}_{g}\left({ }^{\circ} \mathrm{C}\right)^{\mathrm{e}}$ \\
\hline P1 & 526 & 561 & 611 & 56 & 280 \\
P2 & 525 & 560 & 646 & 62 & 321 \\
P3 & 500 & 527 & 645 & 65 & 301 \\
P4 & 477 & 519 & 710 & 68 & 264 \\
P5 & 466 & 498 & 552 & 54 & 310 \\
P6 & 502 & 540 & 609 & 59 & 276 \\
P7 & 432 & 525 & 615 & 60 & 269 \\
P8 & 481 & 523 & 600 & 61 & 281 \\
P9 & 501 & 531 & 659 & 66 & 279 \\
P10 & 462 & 524 & 682 & 67 & 261 \\
P11 & 429 & 582 & 627 & 63 & 274 \\
P12 & 430 & 583 & 625 & 62 &
\end{tabular}

Abbreviation: PABI, poly(arylene benzimidazole).

${ }^{\mathrm{a}} T_{5}=$ temperature of $5 \%$ weight loss.

${ }^{\mathrm{b}} T_{10}=$ temperature of $10 \%$ weight loss.

${ }^{\mathrm{c}} T_{30}=$ temperature of $50 \%$ weight loss.

dThe remaining of the polymer at $600^{\circ} \mathrm{C}$.

eFrom the second heating traces of differential scanning calorimetry measurements conducted with a heating rate of $10^{\circ} \mathrm{C} \mathrm{min}^{-1}$ in nitrogen.

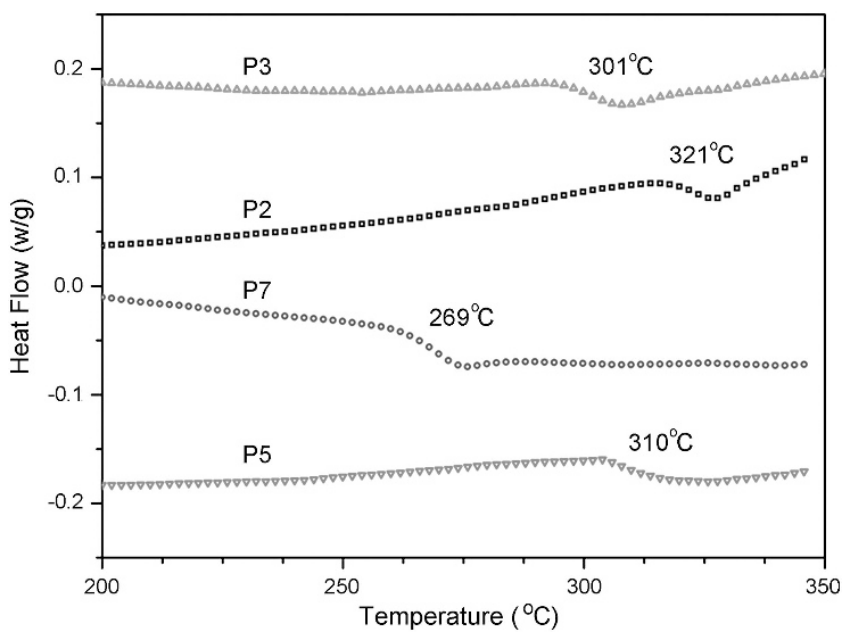

Figure 4 Differential scanning calorimetry curves of PABls. A full color version of this figure is available at Polymer Journal online.

temperature (in Kelvin) at which the simulation was performed. The energy of mixing, $\Delta \mathrm{E}_{\mathrm{mix}}$, required to calculate $\chi$ was calculated using Equation (2):

$$
\Delta \mathrm{E}_{\text {mix }}=\Phi_{\mathrm{P}}\left(\frac{E_{\mathrm{coh}}}{V}\right)_{\mathrm{P}}+\Phi_{\mathrm{S}}\left(\frac{E_{\mathrm{coh}}}{V}\right)_{\mathrm{S}}-\left(\frac{E_{\mathrm{coh}}}{V}\right)_{\text {mix }}
$$

In the above equation, the subscripts $\mathrm{P}, \mathrm{S}$ and mix represent the $\mathrm{CED}$ values by considering the identity: $\mathrm{CED} \equiv\left(\mathrm{E}_{\mathrm{coh}} / V\right)$. The symbols $\Phi_{\mathrm{p}}$ and $\Phi_{s}$ represent the volume fractions of the polymer and the solvent, respectively. Using the calculated value of the mixing energy for the polymer and the solvent, $\chi$ was calculated from Equation (1). As an example, the $\chi$ values for P2 and traditional PSBI determined in different solvents are listed in Table 3. P2 can dissolve in most polar organic solvents, whereas PSBI cannot dissolve in any of the solvents considered. The above simulation results agree well with the experimental results. The polymer solubility was qualitatively determined by the dissolution of $5 \mathrm{mg}$ of solid polymers in $1 \mathrm{ml}$ of organic solvent at room temperature and $50^{\circ} \mathrm{C}$ (see Table 4 ). $\mathrm{P} 2$ was found to be easily soluble in high polar solvents, such as dimethylacetamide, $\mathrm{N}$-methyl2-pyrrolidone and dimethylformamide, whereas it was found to be

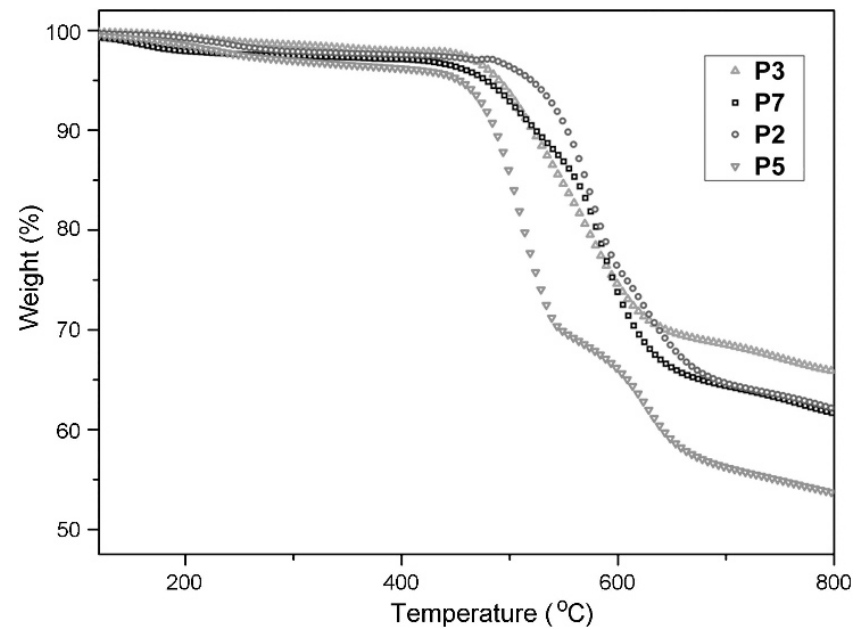

Figure 5 TG curves of PABls. A full color version of this figure is available at Polymer Journal online.

Table 3 Flory-Huggins interaction parameter, $\chi$, for $\mathrm{P} 2 /$ solvent and $\mathrm{PSBI} /$ solvent

\begin{tabular}{lccccc}
\hline & DMF & DMAC & NMP & DMSO & $\mathrm{CHCl}_{3}$ \\
\hline P2 & 0.2733 & 0.2167 & 0.0987 & 0.1594 & 0.6542 \\
PSBI & 0.7856 & 0.9751 & 0.5789 & 0.9652 & 1.3748 \\
\hline
\end{tabular}

Abbreviations: $\mathrm{CHCl}_{3}$, chloroform; DMAc, dimethylacetamide; DMF, dimethylformamide; DMSO, dimethyl sulfoxide; NMP, $N$-methyl-2-pyrrolidone; PABI, poly(arylene benzimidazole).

Table 4 Solubility of PABI

\begin{tabular}{lllllll}
\hline Polymer code & DMF & DMAC & NMP & DMSO & $\mathrm{CHCl}_{3}$ & $\mathrm{THF}$ \\
\hline P1 & ++ & ++ & ++ & +- & ++ & -- \\
P2 & ++ & ++ & ++ & ++ & ++ & -- \\
P3 & ++ & ++ & ++ & +- & +- & -- \\
P4 & ++ & ++ & ++ & +- & ++ & ++ \\
P5 & ++ & ++ & ++ & ++ & ++ & -- \\
P6 & ++ & ++ & ++ & ++ & ++ & ++ \\
P7 & ++ & ++ & ++ & +- & +- & +- \\
P8 & ++ & ++ & ++ & +- & ++ & +- \\
P9 & ++ & ++ & ++ & ++ & +- & -- \\
P10 & ++ & ++ & ++ & +- & ++ & ++ \\
P11 & ++ & ++ & ++ & ++ & ++ & ++ \\
P12 & ++ & ++ & ++ & ++ & ++ & ++ \\
\end{tabular}

Abbreviations: $\mathrm{CHCl}_{3}$, chloroform; DMAc, dimethylacetamide; DMF, dimethylformamide; DMSO, dimethyl sulfoxide; NMP, $\mathrm{N}$-methyl-2-pyrrolidone; PABI, poly(arylene benzimidazole); THF, tetrahydrofuran.

++ , solid polymer was completely dissolved at room temperature; +-- , solid polymer was completely dissolved at $50^{\circ} \mathrm{C} ;--$, solid polymer could swell at $50^{\circ} \mathrm{C}$.

partially soluble in common organic solvents, such as DMSO and chloroform. All of the synthesized polymers showed improved solubility compared with traditional PSBI.

\section{Condensed state and mechanical properties of PABI}

The wide-angle X-ray diffraction patterns of four typical PABI polymers over the $2 \theta$ range of $5-30^{\circ}$ are shown in Figure 6 . Despite the presence of the rigid benzimidazolyl group, all of the polymers revealed essentially amorphous patterns. Obviously, the zigzag polymer chains hindered chain packing and reduced the level of ordering, thus leading to the amorphous nature of the PABI polymers. The amorphous nature of these polymers was also reflected in their good solubility. 
To confirm the amorphous structure, molecular simulations of the degree of order for the PABI polymer chains on the molecular level were performed. Taking P2, P3, P5 and P7 as examples, under threedimensional periodic boundary conditions, the radial distribution function $^{31,32}$ of each of the polymers was calculated by the Forcite module in the Material Studio software package (Figure 7). No obvious peaks in the degree of order were found for $r>4 \AA$, which demonstrates that the synthesized PABI polymers lack long range order and are of amorphous structure, which agrees well with the experimental results in this paper.

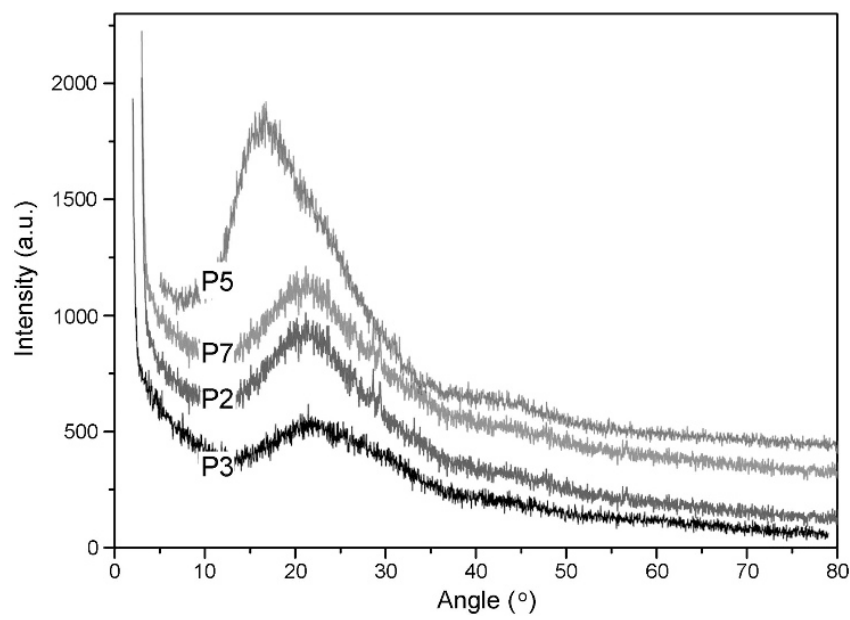

Figure 6 Wide-angle X-ray diffraction curves of PABI. A full color version of this figure is available at Polymer Journal online.

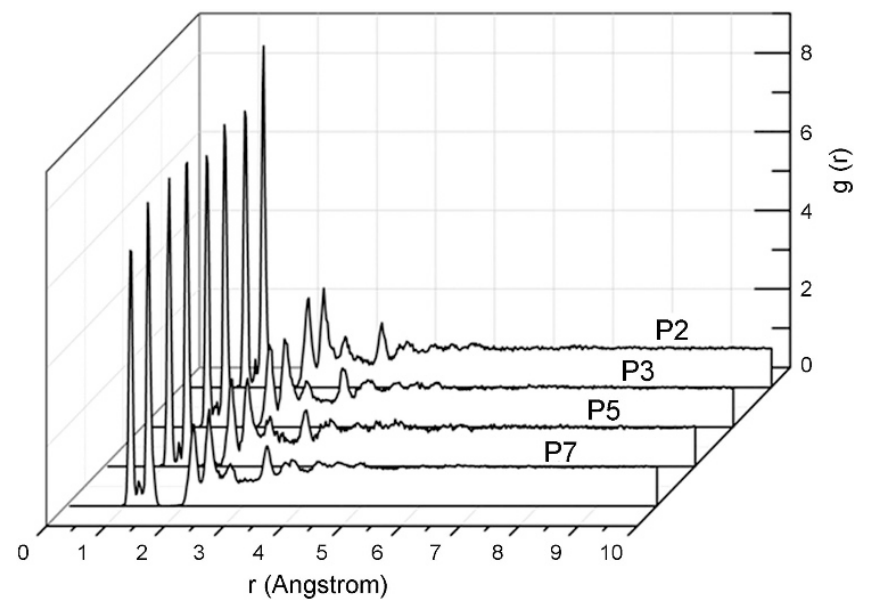

Figure 7 All atomic radial distribution function of P2, P3, P5 and P7.
The extremely rigid polymer chains and relatively closely packing of traditional PBI lead to its poor toughness, which prevents it from being used to form objects with sharp angles. The PABI polymers synthesized in this study were expected to be tougher than the traditional PBI polymers. To verify this improved toughness in theory, molecular simulations of the microstructures for P2 and PSBI were performed using the amorphous cell modules of the Material Studio program. By optimizing without imposing limits on the variations of the cell, an ontology model whose density approached the real density of the polymer was generated. Figure 8 shows the calculated results of the molecular conformation and packing of P2 and PSBI under threedimensional periodic boundary conditions by means of the Connolly surface method. The density, fraction of free volume (FFV), radius of gyration and $d$-spacing of the polymers that are listed in Table 5 were determined using the calculations described above.

In Figure 8, the blue area in the cell represents the free volume $\left(V_{\mathrm{f}}\right)$, and the other areas in the cell represent the occupied volume $\left(V_{\mathrm{o}}\right)$ of the sample. The FFV is a simple and important measurement that is correlated with the primary physical properties of a polymer (Equation (3)).

$$
\mathrm{FFV}=\frac{V_{\mathrm{f}}}{V_{\mathrm{o}}+V_{\mathrm{f}}}
$$

By comparing the FFV of P2 and PSBI (Figure 8), P2 was found to exhibit a relatively high free volume occupancy ratio and a low density, with the 'gap' between its molecular chains being comparatively larger than that of PSBI. Compared with PSBI, P2 possesses relatively better flexibility, which was verified by the experimental results. The stressstrain curves of P2 and PSBI are shown in Figure 9. The experimental results indicated that both P2 and PSBI possess high tensile strength, and P2 exhibited a relatively higher elongation at break (15.5\%); in other words, P2 exhibited better toughness than the traditional PSBI. With regard to structure, all of the PABI polymers, such as $\mathrm{P} 2$, exhibit similar chemical structures, of which the molecular main chains exhibit a ' $\mathrm{Z}$ 'shaped structure. Regarding mechanical performance, all of the PABI polymers possess high elongation while maintaining high tensile strength.

\section{CONCLUSION}

A series of novel PABIs have been obtained by condensation polymerization of aromatic bifluorides with di(benzimidazolyl)benzenes via a C$\mathrm{N}$ coupling reaction. The synthesized PABI polymers exhibited high glass-transition temperatures $\left(T_{\mathrm{g}}>240^{\circ} \mathrm{C}\right)$, good thermal stability with high decomposition temperatures $\left(T_{\mathrm{d}}>450^{\circ} \mathrm{C}\right)$ and excellent solubility in organic solvents such as dimethylacetamide, $N$-methyl-2-pyrrolidone and dimethylformamide; this solubility enables the PABI polymers to be shaped into the required shape from their solutions instead of by the hot pressing and sintering steps that are used for the traditional PBI. In
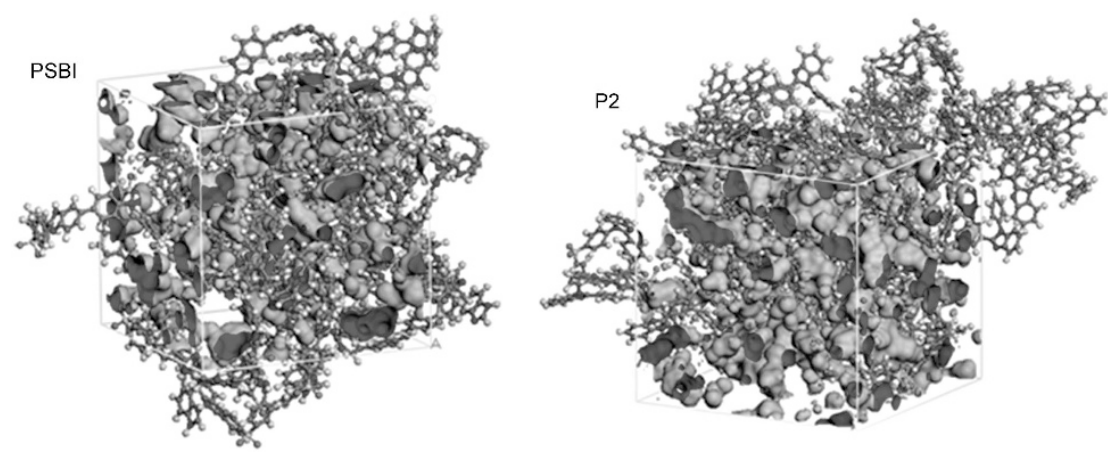

Figure 8 The simulated morphology of P2 and PSBI. A full color version of this figure is available at Polymer Journal online. 
Table 5 The microstructural parameters of P2 and PSBI

\begin{tabular}{lcccc}
\hline & $d_{\text {-spacinga }}\left(A^{\circ}\right)$ & Density $\left(\mathrm{gcm}^{-3}\right)$ & $F F V(\%)$ & Radius of gyration \\
\hline P2 & 6.2 & 1.2332 & 23.69 & 26.10 \\
PSBI & 5.3 & 1.3820 & 19.88 & 27.56 \\
\hline
\end{tabular}

Abbreviations: FFV, fraction of free volume; PSBI, polybenzimidazole with sulfone group. aThe average spacing between the polymer chains.

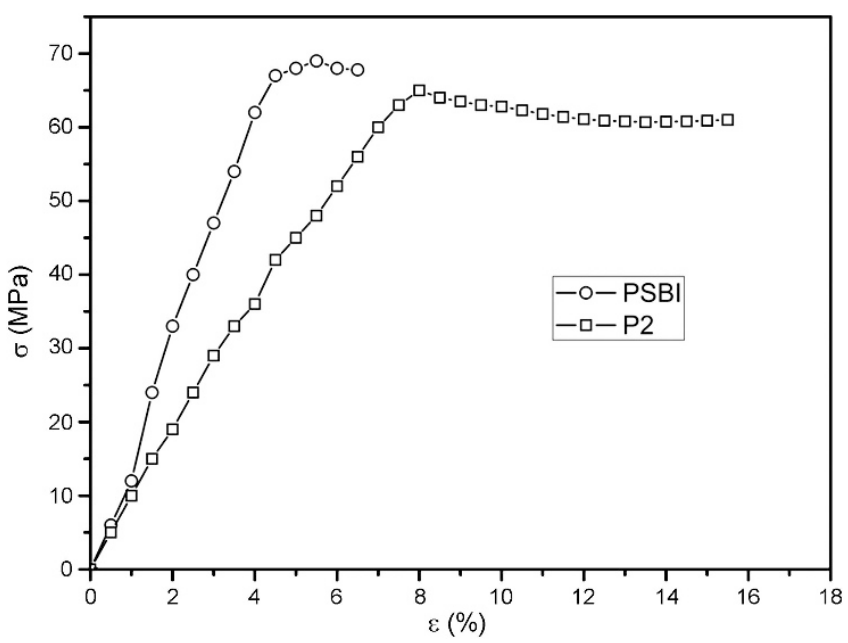

Figure 9 Stress-strain curves of P2 and PSBI.

addition, the PABI polymers exhibited good mechanical behavior with improved toughness and thus can be used both in applications in various high-tech fields and to form shapes with sharp corners. Another major advantage over the traditional PBI polymers is that inexpensive monomers can be used instead of the expensive 3,3',4,4'-tetraaminobiphenyl monomer to produce PABI polymers.

\section{ACKNOWLEDGEMENTS}

This research was financially supported by the Research Fund for the Doctoral Program of the Southwest University of Science and Technology (No. 12zx7129), the Opening Project of State Key Laboratory Cultivation Base for Nonmetal Composites and Functional Materials of the Southwest University of Science and Technology (No. 10zxfk29), the Science and Technology Development Foundation of the Chinese Academy of Physics Engineering (No 2012A0302015; 2012B0302050) and the Foundation of the Double-Hundred Talents of the Chinese Academy of Engineering Physics (Grant No. ZX8078). We thank the Southwest Computing Center of the Chinese Academy of Physics Engineering for their support in performing the computer simulations.

Supporting information available: Text giving detailed characterization of di(benzimidazolyl)benzenes; Figures showing the DSC, TG and XRD of PABI.

$1 \mathrm{Li}$, M. -Q., Shaob, Z. -G. \& Scott, K. A high conductivity $\mathrm{Cs}_{2.5} \mathrm{H}_{0.5} \mathrm{PMo}_{12} \mathrm{O}_{40} \mathrm{O}$ polybenzimidazole $(\mathrm{PBI}) / \mathrm{H}_{3} \mathrm{PO}_{4}$ composite membrane for proton-exchange membrane fuel cells operating at high temperature. J. Power Sources 183, 69-75 (2008).

2 Chuang, S. -W. \& Hsu, S. L. -C. Synthesis and properties of a new fluorine-containing polybenzimidazole for high-temperature fuel-cell applications. J. Polym. Sci. Part $A$ Polym. Chem. 44, 4508-4513 (2006).

3 Hosseini, S. S., Teoh, M. M. \& Chung, T. S. Hydrogen separation and purification in membranes of miscible polymer blends with interpenetration networks. Polymer (Guildf) 49, 1594-1603 (2008)

4 Yu, D. M., Yoon, K., Yoon, Y. J., Kim, T. -H., Lee, J. Y. \& Hong, Y. T. Fabrication and properties of reinforced membranes based on sulfonated poly(arylene ether sulfone) copolymers for proton-exchange membrane fuel cells. Macromol. Chem. Phys. 213, 839-846 (2012).
5 Lin, C. -Y., Kuo, D. -H., Sie, F. -R., Cheng, J. -Y. \& Liou, G. -S. Preparation and characterization of organosoluble polyimide/ $\mathrm{BaTiO}_{3}$ composite films with mechanicaland chemical-treated ceramic fillers. Polym. J. 44, 1131-1137 (2012).

6 Suryani, Chang, C. -M., Liu, Y. -L. \& Lee, Y. M. Polybenzimidazole membranes modified with polyelectrolyte-functionalized multiwalled carbon nanotubes for proton exchange membrane fuel cells. J. Mater. Chem. 21, 7480-7486 (2011).

7 Kumbharkar, S. C. \& Kharul, U. K. N-substitution of polybenzimidazoles: synthesis and evaluation of physical properties. Eur. Polym. J. 45, 3363-3371 (2009).

8 Zhang, L., Ni, Q. -Q., Shiga, A., Fu, Y. \& Natsuki, T. Synthesis and mechanical properties of polybenzimidazole nanocomposites reinforced by vapor grown carbon nanofibers. Polym. Comp. 31, 491-496 (2010).

9 Yu, S., Zhang, H., Xiao, L., Choe, E. -W. \& Benicewicz, B. C. Synthesis of poly (2,2'(1,4-phenylene) 5,5'-bibenzimidazole) (para-PBI) and phosphoric acid doped membrane for fuel cells. Fuel Cell 09, 318-324 (2009).

10 Sousa, T., Mamlouk, M. \& Scott, K. An isothermal model of a laboratory intermediate temperature fuel cell using PBI doped phosphoric acid membranes. Chem. Eng. Sci. $65,2513-2530$ (2010)

11 Xu, C., Wu, X., Wang, X., Mamlouk, M. \& Scott, K. Composite membranes of polybenzimidazole and caesium-salts-of-heteropolyacids for intermediate temperature fuel cells. J. Mater. Chem. 21, 6014-6019 (2011).

12 Xu, C., Cao, Y., Kumar, R., Wu, X., Wang, X. \& Scott, K. A polybenzimidazole/sulfonated graphite oxide composite membrane for high temperature polymer electrolyte membrane fuel cells. J. Mater. Chem. 21, 11359-11364 (2011).

$13 \mathrm{Kim}, \mathrm{S}$. -K., Kim, T. -H., Jung, J. -W. \& Lee, J. -C. Polybenzimidazole containing benzimidazole side groups for high-temperature fuel cell applications. Polymer (Guildf) 50, 3495-3502 (2009).

14 Bai, Z., Putthanarat, S., Rodrigues, S. J. \& Dang, T. D. Properties and performance of composite electrolyte membranes based on sulfonated poly(arylenethioethersulfone) and sulfonated polybenzimidazole. Polymer (Guildf) 52, 3381-3388 (2011).

15 Hosseini, S. S. \& Chung, T. S. Carbon membranes from blends of PBI and polyimides for $\mathrm{N}_{2} / \mathrm{CH}_{4}$ and $\mathrm{CO}_{2} / \mathrm{CH}_{4}$ separation and hydrogen purification. J. Memb. Sci. 328 , 174-185 (2009)

16 Johnson, F. E. \& Cabasso, I. Synthesis and mechanism of PBI phosphonate, poly[2,2' (-m-phenylene)-5,5'-bibenzimidazole phosphonate ester], and its polyphosphonic acid derivatives. Macromolecules 43, 3634-3651 (2010)

17 Shen, C. -H., Jheng, L. -c., Hsu, S. L. -c. \& J. T. -W., Wang Phosphoric acid-doped cross-linked porous polybenzimidazole membranes for proton exchange membrane fue cells. J. Mater. Chem. 21, 15660-15665 (2011).

18 Zhao, C., Lin, H., Han, M. \& Na, H. Covalently cross-linked proton exchange membranes based on sulfonated poly(arylene ether ketone) and polybenzimidazole oligomer. J. Memb. Sci. 353, 10-16 (2010).

19 Yamaguchi, I., Osakada, K. \& Yamamoto, T. Introduction of a long alkyl side chain to poly(benzimidazole)s. N-alkylation of the imidazole ring and synthesis of novel side chain polyrotaxanes. Macromolecules 30, 4288-4294 (1997).

20 Klaehn, J. R., Luther, T. A., Orme, C. J., Jones, M. G., Wertsching, A. K. \& Peterson, E. $\mathrm{S}$. Soluble $\mathrm{N}$-substituted organosilane polybenzimidazoles. Macromolecules 40, 7487-7492 (2007)

21 Hua, M. -Y., Chen, H. -C., Tsai, R. -Y., Leu, Y. -L., Liu, Y. -C. \& Lai, J. -T. Synthesis and characterization of carboxylated polybenzimidazole and its use as a highly sensitive and selective enzyme-free $\mathrm{H}_{2} \mathrm{O}_{2}$ sensor. J. Mater. Chem. 21, 7254-7262 (2011).

22 Smith, J. G. Jr., Connell, J. W. \& Hergenrother, P. M. Synthesis and properties of poly[arylene ether (N-arylenebenzimidazole)]s. J. Polym. Sci. Part A. Polym. Chem. 31, 3099-3108 (1993).

23 Connell, J. W., Hergenrother, P. M. \& Smith, J. G. Jr. Properties of poly (Narylenebenzimidazoles) and their preparation by aromatic nucleophilic displacement. US patent 5410012 (1995).

24 Connell, John W., Hergenrother, Paul M. \& Smith, Joseph G. Jr. Poly (N-arylenebenzimidazoles) via aromatic nucleophilic displacement. US patent 5554715 (1996).

$25 \mathrm{Hlil}$, A. R., Matsumura, S. \& Hay, A. S. Polymers containing di(1H-benzo[d]imidazol-2 $\mathrm{yl}$ )arene moieties: polymerization via $\mathrm{N}-\mathrm{C}$ coupling reactions. Macromolecules 41 1912-1914 (2008)

26 Qi, Y., Gao, Y., Tian, S., Hlil, A. R., Gaudet, J., Guay, D. \& Hay, A. S. Synthesis and properties of novel benzimidazole-containing sulfonated polyethersulfones for fuel cell applications. J. Polym. Sci. Part A Polym. Chem. 47, 1920-1929 (2009).

27 Mir, A. A., Matsumura, S., Hlil, A. R. \& Hay, A. S. Synthesis and properties of polymers containing $2 \mathrm{H}$-benzimidazol-2-one moieties: Polymerization via $\mathrm{N}-\mathrm{C}$ coupling reac tions. ACS Macro Lett. 1, 194-197 (2012).

$28 \mathrm{Li}$, Q., Jensen, J. O., Savinell, R. F. \& Bjerrum, N. J. High temperature proton exchange membranes based on polybenzimidazoles for fuel cells. Prog. Polym. Sci. 34, 449477 (2009).

29 Guan, Y. \& Pu, H. Decheng Wan. Synthesis and properties of poly[2, ' $2^{\prime}-\left(4,4^{\prime}-(2,6\right.$ bis(phenoxy) benzonitrile))-5,5'-bibenzimidazole] for proton conducting membranes in fuel cells. Polym. Chem. 2, 1287-1292 (2011)

30 Connell, J. W., Hergenrother, P. M. \& Smith, J. G. Jr. Synthesis of polybenzimidazoles via aromatic nucleophilic substitution. US patent 5412059 (1995).

31 Hofmann, D., Fritz, L., Ulbrich, J. \& Paul, D. Molecular simulation of small molecule diffusion and solution in dense amorphous polysiloxanes and polyimides. Comp. Theor. Polym. Sci. 10, 419-436 (2000)

32 Zhang, R. \& Mattice, W. L. Flexibility of a new thermoplastic polyimide studied with molecular simulations. Macromolecules 26, 6100-6105 (1993).

Supplementary Information accompanies the paper on Polymer Journal website (http://www.nature.com/pj) 